\title{
Milk Production and Feed Intake of Holstein Cows Given Short (30-d) or Normal (60-d) Dry Periods
}

\author{
M. S. Gulay, M. J. Hayen, K. C. Bachman, T. Belloso, \\ M. Liboni, and H. H. Head \\ Department of Animal Sciences, \\ University of Florida, \\ Gainesville, 32611-0910
}

\section{ABSTRACT}

Eighty-four Holstein cows were utilized to evaluate effects of dry period ( $60 \mathrm{~d}$ vs. $30 \mathrm{~d}$ ), with or without estradiol cypionate (ECP) injections to accelerate mammary involution, on prepartum and postpartum dry matter intake (DMI), body weight (BW), body condition score (BCS), and subsequent milk yield (MY). Treatments were arranged in a $3 \times 2 \times 2$ factorial design that included dry period (30 d dry, $30 \mathrm{~d}$ dry + $\mathrm{ECP}$, and $60 \mathrm{~d}$ dry), prepartum and postpartum bovine somatotropin (bST; $10.2 \mathrm{mg} / \mathrm{d}$ ), and prepartum anionic or cationic diets. To accelerate mammary involution, ECP (15 mg) was injected intramuscularly at dry-off. No interaction of bST or prepartum diet with dry period length was detected on BW, BCS, or MY. No significant effects of dry period length on prepartum DMI, BW, or BCS were detected. Cows with shorter dry periods maintained postpartum BCS better and tended to have greater DMI immediately postpartum. Mean daily yields of milk for dry period groups did not differ during overall lactation period ( 1 to $21 \mathrm{wk}$ ). Injection of ECP at the onset of the 30-d dry period did not affect MY. No significant differences due to dry period length were detected for milk, 3.5\% FCM, or SCM yields during first 10 wk of lactation. Data indicated that a short dry period protocol can be used as a management tool with no loss in the subsequent milk production of dairy cows.

(Key words: dry period, feed intake, lactation, milk yield)

\begin{abstract}
Abbreviation key: CUD $=$ close-up dry, $\mathbf{D 6 0}=60 \mathrm{~d}$ dry control group, $\mathbf{D 3 0}=30$ d dry group, $\mathbf{D 3 0}+\mathbf{E C P}$ $=30 \mathrm{~d}$ dry group injected with ECP, $\mathbf{E C P}=$ estradiol cypionate, FOD $=$ far-off dry, $\mathbf{N E B}=$ negative energy balance.
\end{abstract}

Received September 5, 2002.

Accepted January 7, 2003

Corresponding author: H. H. Head; e-mail: head@animal.ufl.edu.

\section{INTRODUCTION}

Mammary glands of dairy cows require a nonlactating dry period before parturition to achieve maximum milk production during the ensuing lactation (Klein and Woodward, 1943; Swanson, 1965; Smith et al., 1966; Schaeffer and Henderson, 1972; Coppock et al., 1974; Hurley, 1989; Remond et al., 1997). A period of 45 to $60 \mathrm{~d}$ generally has been recommended for the dry period (Coppock et al., 1974; Smith and Todhunter, 1982). The involution of bovine mammary tissue that occurs after cessation of milking is minimal and occurs rapidly (Capuco et al., 1997). The involution, proliferation, and differentiation of mammary secretory epithelial cells that also occur during the nonlactating period are essential for optimum secretory function during the subsequent lactation. Duration of the nonlactating interval is related significantly to subsequent milk production (Klein and Woodward, 1943; Schaeffer and Henderson, 1972; Coppock et al., 1974; Akers and Nickerson, 1983).

Regression of mammary tissue is characterized by dramatic changes in the composition of secretions as the transition occurs from lactating to involuted status (Athie et al., 1996). Estrogen administered at cessation of milk removal accelerated this involution process of mammary tissue (Athie et al., 1996) via a mechanism that involved increased activation of plasminogen (Athie et al., 1997). This observation suggested that administration of exogenous estrogen at the onset of drying off might reduce the dry period length needed for optimum milk production. However, the benefits of using estrogen at dry off remain unclear because cows with 34-d dry periods, when initiated either with or without estrogen treatments, were as productive during subsequent lactation as cows provided 59-d dry periods (Bachman, 2002). Thus, it may be possible to incorporate shorter dry periods into a dry period management scheme without any adverse effects on the milk production during subsequent lactation.

The current standard 60-d dry period has allowed nutritional management of dry cows to be organized 
into two phases: far-off dry (FOD) and close-up dry (CUD). During these dry period phases, the diets fed differ because the physiological status of the cows differs. As a consequence, each change in the diet consumed (lactation diet to FOD diet, FOD diet to CUD diet, CUD diet to lactation diet) forces adaption of the rumen microbial population three times during a short time period. These changes in diet consumed likely augment the decrease in DMI observed as calving approaches (Bertics et al., 1992; Drackley, 1999) and may limit the rate of increase in DMI immediately after parturition. This likelihood is a concern because greater feed intake during early lactation and more efficient fermentation/utilization of ingested feed is desired to reduce extent of negative energy balance associated with copious milk production (Drackley, 1999). If length of the dry period can be decreased to $\sim 30 \mathrm{~d}$, the dry period feeding program could be modified to use a single CUD diet formulated with constituents similar to those used to formulate the lactation diet. This modification should better encourage maintenance of the desired rumen microbial population, as well as support development of rumen papillae (Dirksen et al., 1985). Therefore, this change in feeding program should allow for a greater and more rapid increase in feed intake postpartum in association with the stimulation of a more efficient rumen fermentation and absorption of fermentation end-products. In turn, incidence of metabolic disorders during early lactation should be reduced (Goff and Horst, 1997).

The objective of this study was to compare, relative to the standard 60-d dry period, the effects of 30-d dry period initiated with and without use of estradiol cypionate (ECP in cottonseed oil, $2 \mathrm{mg} / \mathrm{mL}$, Pharmacia \& Upjohn, Kalamazoo, MI), on DMI, BCS, BW, and postpartum milk production.

\section{MATERIALS AND METHODS}

\section{Experimental Design}

Eighty-seven multiparous Holstein cows were assigned randomly to a $3 \times 2 \times 2$ factorial arrangement of treatments approximately 8 to 9 wk before their expected calving dates. The experiment was carried out from September, 2000 through August, 2001. At assignment, parity of cows ranged from 1 to 5 , and BW and BCS ranged from 575 to $870 \mathrm{~kg}$ and from 3.00 to 4.75 , respectively. Cows in the 30 -d dry group (D30; $\mathrm{n}=28)$ and the $30-\mathrm{d}$ dry group injected with ECP (D30 + ECP; $\mathrm{n}=29$ ) were provided an expected 30 -d dry period. Single injections of cottonseed oil (7.5 ml, D30) or same amount of ECP (D30 + ECP) were administered i.m. into the upper caudal face of the hind leg with a 20 -gauge needle at final milk removal. Treat- ment group D60 ( $\mathrm{n}=27)$ was a 60 -d dry control group that received no ECP or cottonseed oil. Actual days dry for D30, D30 + ECP, and D60 groups were $30.6 \pm$ 4.1 (range 19 to $40 \mathrm{~d}$ ), $28.9 \pm 3.7$ (range 16 to $38 \mathrm{~d}$ ), and $61.1 \pm 4.6 \mathrm{~d}$ (range 53 to $70 \mathrm{~d}$ ). Only seven of short dry period cows $(n=57)$ had dry periods $>35 d$. Mean parity of cows in the D30, D30 + ECP, and D60 groups were $2.7,2.5$, and 2.6 , respectively. One-half of the cows in D30 ( $\mathrm{n}=14), \mathrm{D} 30+\mathrm{ECP}(\mathrm{n}=15)$, and D60 ( $\mathrm{n}$ = 13) were injected biweekly with bST $(0.4 \mathrm{ml}$ of bST; POSILAC ${ }^{\circledR}$ ). This quantity of POSILAC provided $\sim 10.2$ $\mathrm{mg} \mathrm{bST} / \mathrm{d}$; injections began $\sim 28 \mathrm{~d}( \pm 3 \mathrm{~d}$ ) before expected calving dates and continued through $60 \mathrm{~d}$ postpartum. After $60 \mathrm{~d}$, all cows on experiment received the full dose of POSILAC biweekly (500 mg/14 d). One-half of the cows in D30, D30 + ECP, and D60 were fed either an anionic or cationic diet during the $3 \mathrm{wk}$ before expected calving. One cow from D60 + bST fed the cationic diet, one cow from D30 fed the anionic diet, and one cow from D30 + ECP fed the anionic diet were removed from the experiment due to paratuberculosis, severe mastitis, and displacement of abomasum, respectively. A total of 84 cows completed the experiment (150 d) and were included in data analyses.

\section{Feeding Program}

Cows in D60 were dried off $60 \mathrm{~d}$ before expected calving and were moved to the dry herd and fed the herd FOD diet, while cows in D30 and D30 + ECP remained in the milking herd until dry off at $30 \mathrm{~d}$ prepartum. All cows were housed and managed in a free-stall barn beginning $30 \mathrm{~d}$ before expected calving and trained to use electronic feed gates (American Calan, Inc., Northwood, NH). Feeding occurred once daily (1000 to $1200 \mathrm{~h}$ ), with daily feed adjustments made to allow for 5 to $10 \%$ daily refusals. During the first week of the trial, while being trained to use the Calan gates, cows were fed a cationic CUD ( $\cong 20 \mathrm{mEq} / 100 \mathrm{~g} \mathrm{DM})$ formulated for the average weight of the cows. Starting at 3 wk before their expected calving date, cows were fed an anionic CUD ( $-10 \mathrm{mEq} / 100 \mathrm{~g} \mathrm{DM})$, or they continued on the same cationic CUD (Table 1). After parturition, all cows were fed a total mixed ration (TMR) based on corn silage, whole cottonseeds (WCS), and grain concentrate. This ration met the requirements of high-producing lactating cows (Table 2; NRC, 1989).

\section{Body Condition Scores and Body Weights}

Body condition scores ( 1 to 5 , thin to fat; Ferguson et al., 1994) and BW of cows were recorded at 60 and $30 \mathrm{~d}$ before expected calving and thereafter weekly on the same day each week before a.m. feeding or milking 
Table 1. Dry matter concentrations and chemical composition of anionic and cationic close-up dry (CUD) diets fed to Holstein cows. ${ }^{1}$

\begin{tabular}{|c|c|c|}
\hline & $\begin{array}{l}\text { Anionic } \\
\text { CUD Diet }\end{array}$ & $\begin{array}{l}\text { Cationic } \\
\text { CUD Diet }\end{array}$ \\
\hline Ingredients & \multicolumn{2}{|c|}{ Percentage } \\
\hline Corn silage & 41.40 & 45.46 \\
\hline Alfalfa hay & - & 5.00 \\
\hline Corn grains & 22.52 & 18.28 \\
\hline Cottonseed hulls & 10.66 & 11.17 \\
\hline Soybean meal & 8.89 & 8.38 \\
\hline Cottonseed with lint & 7.18 & 5.20 \\
\hline Prolak & 2.43 & 2.55 \\
\hline Springer minerals & 6.44 & 2.92 \\
\hline Salt & 0.48 & 0.50 \\
\hline Sodium bicarbonate & - & 0.54 \\
\hline Chemical composition & \multicolumn{2}{|c|}{ - Percentage (DM basis) } \\
\hline $\mathrm{DM}(\%)$ & 63.04 & 62.07 \\
\hline $\mathrm{CP}$ & 14.87 & 14.88 \\
\hline Sol CP $\mathrm{CP}^{2}$ & 28.11 & 29.25 \\
\hline $\mathrm{ADF}$ & 23.93 & 26.17 \\
\hline $\mathrm{NDF}$ & 37.29 & 40.53 \\
\hline $\mathrm{EE}^{3}$ & 4.15 & 3.81 \\
\hline TDN & 67.55 & 67.22 \\
\hline $\mathrm{NE}_{\mathrm{L}}(\mathrm{Mcal} / \mathrm{kg})$ & 1.54 & 1.52 \\
\hline $\mathrm{K}^{+}$ & 1.02 & 1.14 \\
\hline $\mathrm{Na}^{+}$ & 0.27 & 0.40 \\
\hline $\mathrm{Cl}^{-}$ & 1.08 & 0.82 \\
\hline $\mathrm{S}^{-2}$ & 0.34 & 0.33 \\
\hline $\mathrm{Ca}^{+2}$ & 1.66 & 1.07 \\
\hline $\mathrm{P}^{+}$ & 0.35 & 0.38 \\
\hline Calculated DCAD ${ }^{4}$ & -10.0 & +19.4 \\
\hline
\end{tabular}

${ }^{1}$ From NEDHIA Forage Laboratory, Ithaca, NY, analyses of components.

${ }^{2}$ Percentage of the CP.

${ }^{3}$ Ether extract.

${ }^{4} \mathrm{Meq} / 100 \mathrm{~g} \mathrm{DM}$.

( 0800 to $1200 \mathrm{~h}$ ) through $28 \mathrm{~d}$ postpartum. Thereafter, $\mathrm{BCS}$ and BW were determined biweekly up to $\sim 100$ d postpartum.

\section{Milk Samples}

Milk samples were collected on the same day each week at three consecutive milkings $(0830,1700$, and $0130 \mathrm{~h}$ ) during the first $10 \mathrm{wk}$ of lactation for analyses of milk constituents. Samples (50-ml) were analyzed for fat, protein, and SCC contents at Southeast Milk Laboratory, Inc. (Belleview, FL). Milk yield was recorded at each daily milking from 3 to $150 \mathrm{~d}$ postpartum.

\section{Statistical Analyses}

Data for BW, BCS, DMI, and MY were analyzed as a nested design by Least squares ANOVA procedures of SAS (1991). PROC MIXED procedure of SAS was used to estimate individual daily and/or weekly Least squares means for specific variables and treatments (Littell et al., 2000).
Table 2. Dry matter concentrations and chemical composition of total mixed ration (TMR) with whole cottonseeds (lactation diet) fed to Holstein cows ${ }^{1}$.

\begin{tabular}{lc}
\hline Ingredients & TMR \\
\hline & Percentage \\
Corn silage & 22.38 \\
Alfalfa hay & 11.69 \\
Cottonseed Hulls & 5.07 \\
Citrus pulp & 9.94 \\
Hominy & 16.08 \\
Distillers grains & 10.42 \\
Soybean meal & 8.38 \\
Whole cottonseed & 10.71 \\
Mineral mix & 5.33 \\
Chemical composition & Percentage (DM basis) \\
DM (\%) & 62.35 \\
CP & 17.18 \\
Sol CP & 32.66 \\
ADF & 22.58 \\
NDF & 34.66 \\
EE & 3.56 \\
TDN & 67.83 \\
NE & $(M c a l / k g)$ \\
\hline
\end{tabular}

${ }^{1}$ From NEDHIA Forage Laboratory, Ithaca, NY, analyses of components.

${ }^{2}$ Percentage of the CP.

${ }^{3}$ Ether extract.

Mathematical models included the main effects dry period treatments (DRY; D30, D30 + ECP, and D60), bST, prepartum diet treatment (DIET), and season (SEA; I = cows with dry periods during hotter months (September, October, March, April, and May), II = cows with dry periods during cooler months (November, December, January, and February), all their interactions, with cow (bST*DRY*DIET*SEA) as the error term, as well as weeks or days to the highest order significant for overall prepartum and postpartum periods.

\section{RESULTS}

\section{Changes in BW and BCS}

Prepartum. No significant effects of dry period treatment, or interaction of bST or prepartum diet with dry period treatment were detected during the overall prepartum period (wk -8 to -1 ). The mean BW of D60 cows on d 60 was significantly greater when these cows were dried off compared to BW of D30 or D $30+$ ECP cows (678 vs. 636 and $638 \mathrm{~kg}$, respectively) at $30 \mathrm{~d}$ before their dry off dates (Figure 1). However, at the time of their dry off at $30 \mathrm{~d}$ prepartum, BW of the two D30 groups of cows did not differ significantly $(P=0.61)$ from D60 cows on d 30 prepartum (694 vs. 667 and $672 \mathrm{~kg}$, respectively). Cows in all treatment groups gained BW during the weeks following dry off, and at $1 \mathrm{wk}$ before calving, the increases in $\mathrm{BW}$ were 


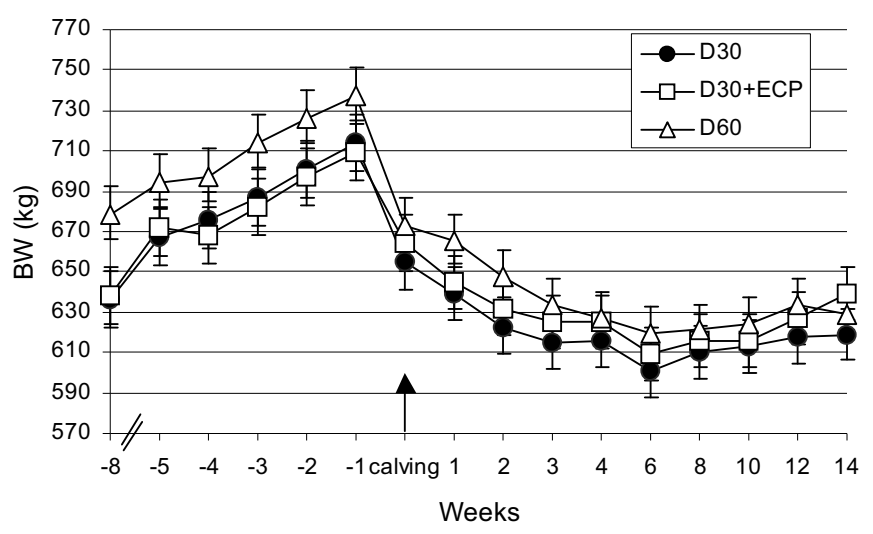

Figure 1. Body weights of Holstein cows during the prepartum and postpartum periods. Arrow indicates calving.

11,10 , and $9 \%$ for D30, D30 + ECP, and D60, respectively (Figure 1). In contrast to BW, mean BCS did not differ at -8 wk (Figure 2); mean BCS for D30, D30 $+\mathrm{ECP}$, and D60 were 3.27, 3.31, and 3.26, respectively. Respective mean BCS increased slightly $(0.10,0.08$, and 0.06 points) by wk -5 and continued to increase during the prepartum period (Figure 2). Increases in mean BCS during the last $30 \mathrm{~d}$ of the dry period for D30, D30 + ECP, and D60 were 0.22, 0.15, and 0.13 points, respectively.

Postpartum. No significant effects of bST or prepartum diet were detected on BW or BCS. Mean BW of cows during the postpartum period (wk 0 through 14) did not differ due to dry period treatment. Cows in all three treatment groups showed an acute decrease in mean BW after calving, as would be expected. Decreases in BW were similar from wk -1 prepartum to wk 6 postpartum, the time at which cows stopped losing BW (Figure 1). Losses in BW for D30 (14.6\%), D30

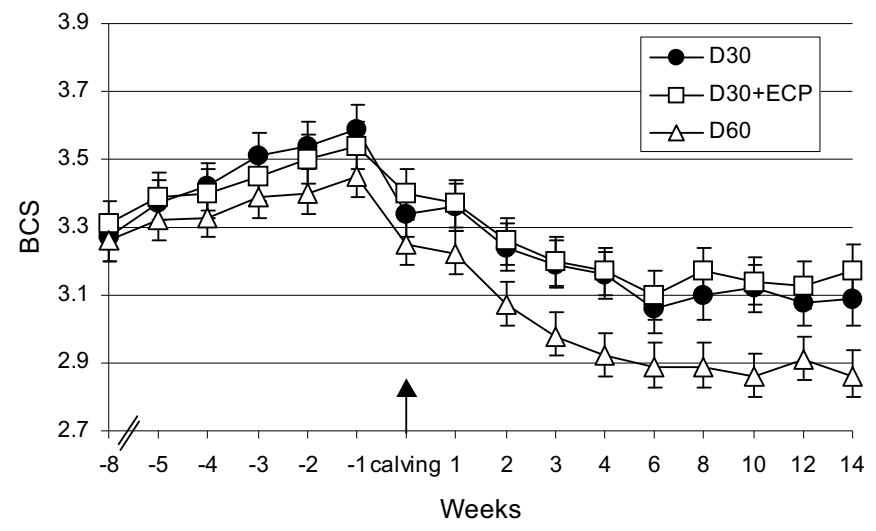

Figure 2. Body condition scores of Holstein cows during the prepartum and postpartum periods. Arrow indicates calving.
$+\operatorname{ECP}(13.1 \%)$, and D60 (15.7\%) were similar from wk -1 through wk 8 . Birth weights of calves did not differ $(37.0 \pm 1.4,36.0 \pm 1.4$ and $39.2 \pm 1.5 \mathrm{~kg}$ for D30, D30 + ECP, and D60, respectively).

Postpartum changes in mean BCS of cows differed significantly $(P<0.04)$ among dry period treatments (Table 3). Following calving, BCS decreased for all three groups; however the decrease was greater for D60 cows and it persisted throughout the experiment (Figure 2). The BCS reached lowest values around wk 6 postpartum for all groups. Mean BCS at wk 8 were greater than 3.0 for D30 (3.10) and D30 + ECP (3.17) cows but not for D60 cows (2.89; Figure 2).

\section{Changes in DMI}

Prepartum. No differences were detected in mean prepartum DMI of cows in the three dry period treatments (Table 3). No interactions between bST or diet fed prepartum and DMI were detected. Overall, DMI 3 wk before calving was about $17 \mathrm{~kg}$ for cows across treatment groups (Table 3, Figure 3). No decreases in DMI occurred before $8 \mathrm{~d}$ before calving (Figure 3), but decreases in mean DMI of 32,38 , and $45 \%$ for cows in D30, D30 + ECP, and D60, respectively, (Figure 3) occurred during the last $4 \mathrm{~d}$ prepartum.

Postpartum. No significant effects of dry period treatment, or interaction of bST or prepartum diet with dry period treatment were detected during the overall postpartum period. No differences in mean DMI were detected among the three dry period treatment groups after parturition (Table 3), although D60 cows tended to have lower mean DMI (Figure 3). In general, trends for mean DMI of D60 cows tended to be less throughout the 28-d period than for cows in the two 30-d dry groups (Table 3). Mean postpartum DMI was greatest for cows in D30 + ECP $(27 \mathrm{~kg} / \mathrm{d})$, lower for D30 cows $(25.7 \mathrm{~kg} / \mathrm{d})$, and least for D60 cows $(24.7 \mathrm{~kg} / \mathrm{d})$. However, at d 28 mean DMI was around $30 \mathrm{~kg} / \mathrm{d}$ for cows in the three dry period treatment groups (Figure 3). Expressed as a percentage of BW, DMI differed among groups $(P<0.01)$. Similar to results for DMI $(\mathrm{kg} / \mathrm{d})$, as a percentage of BW, greatest DMI was by cows in D30 + ECP (4.28\%), intermediate for cows in D30 (4.09\%), and least for cows in D60 (3.86\%; Table 3 and Figure 4).

All cows were in negative energy balance (NEB) during the first $4 \mathrm{wk}$ postpartum. However, mean NEB for cows in D30 was significantly less $(-13.77 \mathrm{Mcal} / \mathrm{d})$ than for cows in D30 + ECP group ( $-17.04 \mathrm{Mcal} / \mathrm{d})$ or for cows in D60 (-20.68 Mcal/d) during the first $4 \mathrm{wk}$ postpartum $(P<0.06)$.

Milk, 3.5\% FCM, and SCM yields. Least squares means for milk, 3.5\% FCM and SCM yields during 
Table 3. Least squares means (LSM) and SE of BW, BCS, and DMI during prepartum and postpartum periods for Holstein cows in three dry period groups.

\begin{tabular}{|c|c|c|c|c|c|c|}
\hline \multirow[b]{3}{*}{ Measurements } & \multicolumn{6}{|c|}{ Prepartum ( -28 to $-1 \mathrm{~d})$} \\
\hline & \multicolumn{3}{|c|}{ Dry period treatments ${ }^{1}$} & \multicolumn{3}{|c|}{ Contrasts $^{2}$} \\
\hline & D30 (1) & $\mathrm{D} 30+\operatorname{ECP}(2)$ & D60 (3) & 1 vs 2 & 1 vs 3 & 2 vs 3 \\
\hline BW (kg) & $677.0 \pm 12.0$ & $676.1 \pm 13.9$ & $703.2 \pm 14.2$ & NS & NS & $\mathrm{NS}$ \\
\hline BCS & $3.44 \pm 0.06$ & $3.43 \pm 0.07$ & $3.34 \pm 0.07$ & NS & NS & NS \\
\hline DMI (\%BW) & $2.41 \pm 0.09$ & $2.36 \pm 0.13$ & $2.33 \pm 0.11$ & NS & NS & NS \\
\hline DMI (kg/d) & $16.6 \pm 0.57$ & $16.3 \pm 0.79$ & $16.8 \pm 0.71$ & NS & NS & NS \\
\hline
\end{tabular}

\begin{tabular}{|c|c|c|c|c|c|c|}
\hline \multirow[b]{3}{*}{ Measurements } & \multicolumn{6}{|c|}{ Postpartum ( 0 to $28 \mathrm{~d})$} \\
\hline & \multicolumn{3}{|c|}{ Dry period treatments ${ }^{1}$} & \multicolumn{3}{|c|}{ Contrasts } \\
\hline & D30 (1) & $\mathrm{D} 30+\operatorname{ECP}(2)$ & D60 (3) & 1 vs 2 & 1 vs 3 & 2 vs 3 \\
\hline BW (kg) & $615.6 \pm 10.9$ & $626.6 \pm 12.5$ & $634.1 \pm 12.7$ & NS & NS & NS \\
\hline BCS & $3.16 \pm 0.05$ & $3.19 \pm 0.06$ & $2.96 \pm 0.06$ & NS & $P<0.04$ & $P<0.02$ \\
\hline DMI (\%BW) & $4.09 \pm 0.13$ & $4.29 \pm 0.18$ & $3.86 \pm 0.16$ & NS & NS & $P<0.08$ \\
\hline DMI (kg/d) & $25.7 \pm 0.78$ & $27.0 \pm 1.08$ & $24.7 \pm 0.96$ & NS & NS & NS \\
\hline
\end{tabular}

${ }^{1} \mathrm{D} 30=30$-d dry period with no ECP, D30 + ECP = 30-d dry period with ECP, and D60 = 60-d dry period. ${ }^{2} \mathrm{NS}=P>0.10$.

first 10 wk for cows in the three dry period treatment groups are shown in Table 4. No significant differences were detected due to dry period for any measure of MY evaluated. Cows in D60 had slightly greater numerical milk $(39.4 \mathrm{~kg} / \mathrm{d}), 3.5 \% \mathrm{FCM}(41.6 \mathrm{~kg} / \mathrm{d})$, and SCM $(39.8$ $\mathrm{kg} / \mathrm{d})$ yields than cows in D30 $(37.4,39.3$, and $37.9 \mathrm{~kg} /$ $\mathrm{d}$, respectively) or cows in D30 + ECP $(37.5,40.7$, and $39.1 \mathrm{~kg} / \mathrm{d}$, respectively), but, as indicated, MY values did not differ significantly (Figure $5 ; P=0.66$ ). Similarly, no significant differences in mean percentages of protein $(2.78,2.93$, and $2.89 \%)$, fat $(3.90,4.09$, and $3.84 \%)$, or SCC $\left(485,484\right.$ and $\left.309 \times 10^{3}\right)$ were detected due to prepartum dry treatments (D60, D30 + ECP, and $\mathrm{D} 30$, respectively) during the first 10 -wk lactation period (Table 4). Furthermore, MY during first $21 \mathrm{wk}$ did not differ significantly due to dry period treatment

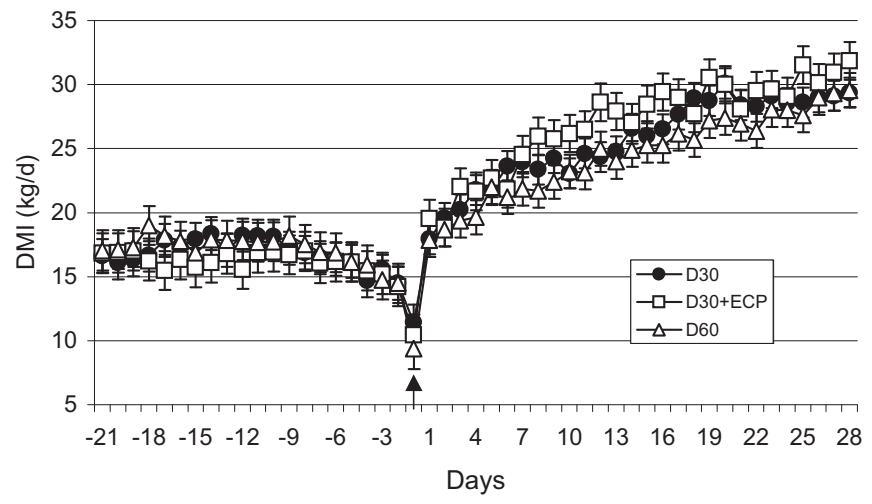

Figure 3. Dry matter intake of Holstein cows during the prepartum and postpartum periods. Arrow indicates calving.
(Table $4 ; P=0.93$ ). As expected, bST injections resulted in $7.9,8.2$, and $8.0 \%$ increases in mean daily milk, $3.5 \% \mathrm{FCM}$, and SCM yields during the first $60 \mathrm{~d}$ of lactation but there were no interactions detected among dry period, diet, and bST for any measure of milk production.

The current lactation 305-d ME yields of cows were also analyzed. Cows in D30 (10,674 $\pm 307 \mathrm{~kg})$, D30 + $\operatorname{ECP}(10,448 \pm 329 \mathrm{~kg})$, and D60 $(10,396 \pm 343 \mathrm{~kg}) \mathrm{had}$ similar previous lactation 305-d ME milk yields (Table 4; $P=0.83$ ). The current 305-d ME were $9586 \pm 343$, $9959 \pm 375$ and $9700 \pm 385 \mathrm{~kg}$ for cows in D30, D30 + ECP, and D60, respectively (Table 4; $P=0.65$ ). When current 305-d milk yields were adjusted for previous 305-d actual milk yields of cows assigned to the three dry groups, no significant differences were detected $(9580 \pm 321,9960 \pm 344$, and $9836 \pm 358 \mathrm{~kg}$, respectively; Table $4 ; P=0.54$ ).

\section{DISCUSSION}

A 55- to 60-d dry period has been widely recommended and adopted based on observations that this resulted in maximum milk production during the subsequent lactation (Klein and Woodward, 1943; Schaeffer and Henderson, 1972; Coppock et al., 1974; Dias and Allaire, 1982). However, the current study did not detect any benefit of setting the dry period length at $60 \mathrm{~d}$. Through $21 \mathrm{wk}$, the mean unadjusted milk yields of cows in the two 30-d groups (D30; $5950 \pm 117 \mathrm{~kg}$ and D30 + ECP; $5857 \pm 150 \mathrm{~kg}$ ) were as much as for those that had the 60 -d dry period $(5835 \pm 144 \mathrm{~kg})$. Similar results were found when data were adjusted 
Table 4. Least squares means (LSM) and SE of milk, 3.5\% FCM, and SCM yields and SCC and milk components of Holstein cows provided different dry periods during early lactation.

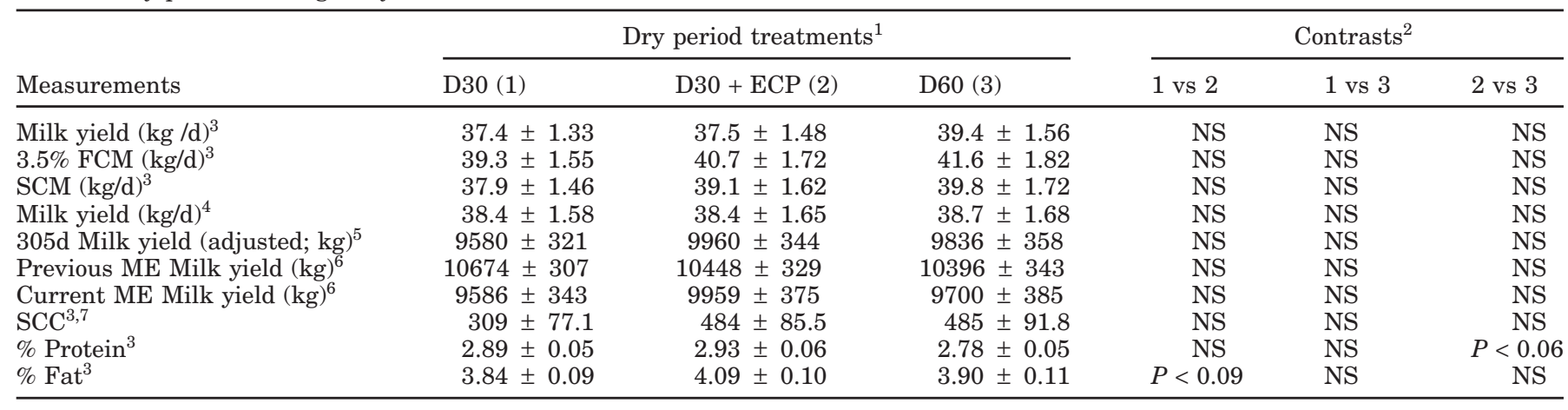

${ }^{1} \mathrm{D} 30=30-\mathrm{d}$ dry, D30 + ECP $=30$-d dry + ECP, D60 = 60-d dry.

${ }^{2} \mathrm{NS}=P>0.10$.

${ }^{3}$ During 1 to 10 wk postpartum.

${ }^{4}$ During 1 to 21 wk postpartum.

${ }^{5}$ Adjusted for previous actual 305-d milk yield.

${ }^{6} 305$-d Mature equivalent milk yield.

${ }^{7} \mathrm{SCC}=$ somatic cell count $\times 1000$.

by statistical analyses (Table 4 ). In addition, the 305 d ME milk production for these groups did not differ before or after adjustment for previous 305-d ME yields. On average, cows in the two 30-d dry groups produced an additional $\sim 510 \mathrm{~kg}$ of milk during the 30 $d$ that their current lactation was extended prior to dry off. Others have reported similar results (Schairer, 2001; Bachman, 2002). Cows $(\mathrm{n}=15)$ with 34-d dry periods produced as much 305-d ME milk as herdmates $(\mathrm{n}=19)$ that had 57-d dry period (9125 vs. 8986 kg; Bachman, 2002). Similarly, 10 cows produced 11,008 kg 305-d ME milk following a 32-d dry period, whereas nine cows with 61-d dry period from the same herd produced 10,529 $\mathrm{kg}$ (Schairer, 2001). These au-

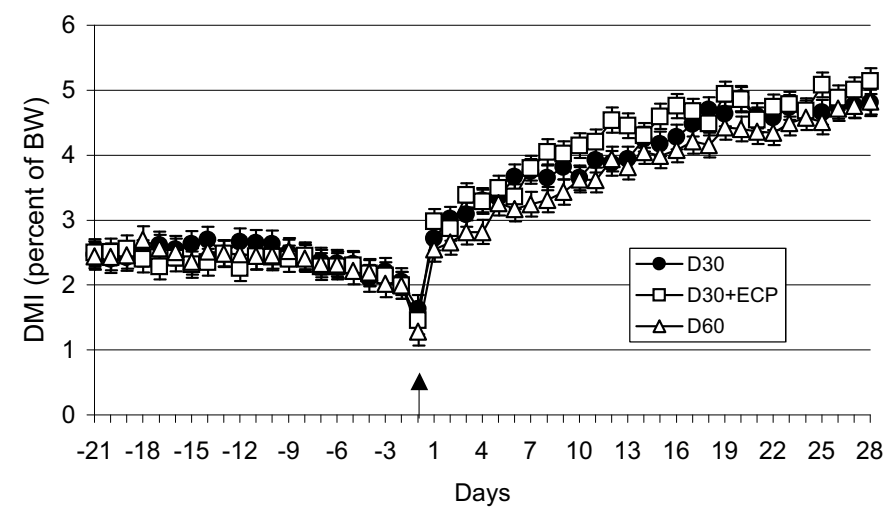

Figure 4. Dry matter intake expressed as percent body weight of Holstein cows during the prepartum and postpartum periods. Arrow indicates calving. thors concluded that shorter dry periods can be a profitable management practice for dairy farmers.

Earlier recommendations that dry periods should not be $<50 \mathrm{~d}$ were based on results from retrospective analysis of observational data. For example, Klein and Woodward (1943) utilized 1139 lactation records from Dairy Herd Improvement Association (DHIA) to study dry period length. They determined that the optimum dry period was $55 \mathrm{~d}$ for cows producing $\sim 5000 \mathrm{~kg}$ of $4 \%$ FCM with a 12-mo calving interval. This recommendation was made, although the average milk production of 40- to 49- and 60- to 69-d dry periods did not differ significantly from the production that followed the 55-d dry period. Schaeffer and Henderson (1972) concluded that cows with dry periods of 50 to 59 $\mathrm{d}$ had greatest milk production during the subsequent lactation. Moreover, Funk et al. (1987) reported that cows dry for 60 to $69 \mathrm{~d}$ produced significantly more milk $(\sim 459 \mathrm{~kg})$ in the subsequent lactation than cows dry for $<40 \mathrm{~d}$. Effects of days dry on milk yields of first$(\mathrm{n}=11,583)$, second- $(\mathrm{n}=7143)$, and third- $(\mathrm{n}=6102)$ lactation Holstein cows from Zimbabwe and North Carolina were evaluated by Makuza and McDaniel (1996). Milk yields for 30- to 39-, 40- to 49-, and 50to 59 -d dry cows were 610,633 , and $202 \mathrm{~kg}$ less than for 60-d dry periods in both locations, and there was little advantage observed for dry periods $>60 \mathrm{~d}$.

Observational MY data, as are often used, may be affected by many factors other than dry period length, that are highly related to subsequent milk production. For example, data within existing records often will not include the reason why specific cows were dried 


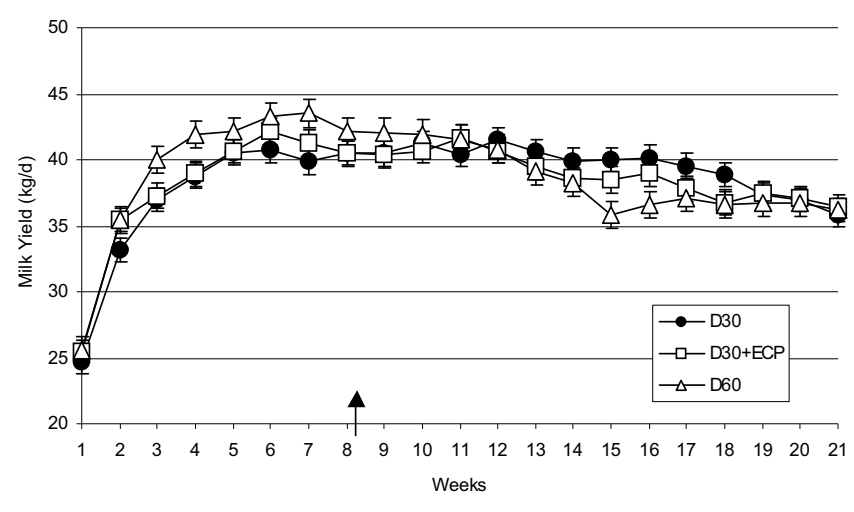

Figure 5. Milk production of Holstein cows during early lactation. Arrow indicates the time full dose of bST injection started.

off earlier or later than most other cows, such as spontaneous early cessation of lactation, insufficient milk production, or mastitis. In fact, low-producing cows tend to have longer dry periods (Sorensen et al., 1993). Likewise, the reason why cows had shorter dry periods most often could not be determined from the milk yield records that were analyzed to determine optimum dry period length. Cows included in short dry period groups would include those that calved earlier than expected due to physiological problems, sickness, or exposure to heat stress, et cetera. These situations/ scenarios could bias the estimated effect of days dry on subsequent milk yield because potential or actual problems experienced during early lactation, in conjunction with the early calving, would affect subsequent lactational performance. Thus, estimation of the true effects of dry period length on subsequent milk production through retrospective analysis of milk production seems more likely to bias results in favor of the 60-d dry period, because cows were not assigned at random to the dry period lengths reported.

Few studies have used designed experimental protocols that assigned cows at random to the dry period treatments (Coppock et al., 1974; Sorensen and Enevoldsen, 1991; Schairer, 2001; Bachman, 2002). For example, Coppock et al. (1974) conducted a 42-mo field trial $(\mathrm{n}=1019)$ and evaluated effects of 20-, 30-, 40-, $50-$, or 60-d dry periods on subsequent milk production and concluded that $<40$-d dry resulted in a significant loss of milk production. However, statistical and experimental design of this study has been criticized by others (Sorensen and Enevoldsen, 1991: Sorensen et al., 1993). In another study, Sorensen and Enevoldsen (1991) estimated the effect of planned 4-, 7-, and 10wk dry periods on subsequent lactational yield of dualpurpose cows ( $\mathrm{n}=366$, Red Danish and Danish Black and White breeds). They found that compared to a 7- wk period, a 4-wk dry period resulted in decreased milk production. However, Schairer (2001) and Bachman (2002) reported that cows with short dry periods $(<34 \mathrm{~d})$ with no special treatment or medication were as productive as their herdmates with dry periods $>57 \mathrm{~d}$.

Clearly, cows need a dry period if they are to reach maximum possible MY, which is determined by genetics and management (Swanson, 1965; Smith et al., 1966). The exact length of time needed for the dry period has not been established definitively and is likely influenced by the time needed for mammary involution. The time course and degree of mammary involution that occurs in cows differ noticeably from those seen in rodents (Capuco et al., 1997). Compared to rodents, involution of the bovine mammary gland occurs at a slower rate and with greater retention of the alveolar structure throughout the period of involution (Capuco and Akers, 1999). Moreover, it has been proposed that mammary involution of dairy cows is completed by 25 -d into the dry period. A nonsecretory state was achieved at $35 \mathrm{~d}$ prepartum following cessation of milk removal at $60 \mathrm{~d}$ prepartum, as evidenced by the complete absence of secretory vesicles or fat droplets within epithelial cells and by a reduction of mammary luminal area to its nadir (Capuco et al., 1997). This finding, which differs greatly from the previously held view on speed of and extent of involution in dairy cows (Lascelles and Lee, 1978; Hurley, 1989), supports the results obtained during the current and previous studies (Schairer, 2001; Bachman, 2002). Shorter dry periods did not negatively affect subsequent lactational performance compared to cows provided a 60-d dry period.

Although estradiol $17 \beta$ injections have been suggested as a way to increase rate of mammary involution in cows (Athie et al., 1996), no benefits of ECP injection were shown nor were differences among dry period treatments detected for any measure of MY (Table 4). This suggests that mammary gland involution and remodeling apparently can be completed within $\sim 30 \mathrm{~d}$. Thus, a 30-d dry period should be long enough to allow appropriately managed cows in good body condition to produce amounts of milk following parturition that is similar to those of cows that had essentially double the dry period length. Indeed, shortening the dry period did not decrease actual yield of milk during the first $21 \mathrm{wk}$ postpartum or the 305-d ME yields. Based on milk production, it appears that $\sim 30$-d dry period was sufficient time for the mammary gland to involute and subsequently remodel with differentiation of the epithelial cell population. Certainly, favorable results of this and other studies (Schairer, 2001; Bachman, 2002) strongly supports the need for 
further research efforts in this area to evaluate the effect of short dry period length on health, calving interval, and cow turnover rates.

In the current experiment, diet changes in D60 cows (from lactation diet to FOD diet, from FOD diet to CUD diet, and from CUD diet to lactation diet) likely required the rumen microbes to adapt three times during a short time period. These adaptive changes may have limited the increase in feed intake occurring immediately after parturition. On the other hand, fewer changes in the diet of the 30-d dry cows (lactation to CUD, CUD to lactation) might have encouraged maintenance of a more stable rumen microbial population and better development of rumen papillae (Dirksen et al., 1985). Changing the diet of the animal provokes a period of transition in the rumen microbial population such that the proportions of the various microbial species in the rumen will shift to a new balance, one which best accommodates the dietary change. This adaptation may require several days to weeks (Goff and Horst, 1997). Thus, it may be advantageous to have fewer diet changes prepartum and to have cows replenish body condition before they are dried off. Our results suggested that if an adequate BCS can be achieved before drying off $(\geq 3.25)$, there were no advantages, based on subsequent milk production, of providing cows with a $60 \mathrm{~d}$ dry period compared to a 30-d dry period.

Although cow numbers were too few to critically evaluate health status, no apparent health and/or calving problems or benefits were observed for the cows across the dry period treatments. Importantly, no effect of ECP on early calvings and/or abortions was observed during the experiment, even though some cows $(n=37)$ calved during the months of September, October, March, April, and May, which were hotter and somewhat more stressful time periods due to higher temperatures and humidity. On the other hand, because of the risk of early calvings due to heat stress, use of ECP and short dry period $(<30 \mathrm{~d})$ combinations should be tested during the hottest summer months to evaluate effects on subsequent health and production especially if dry periods would be actually reduced to $<30 \mathrm{~d}$ during these months.

\section{CONCLUSION}

There was no evidence that shortening the dry period to $\sim 30 \mathrm{~d}$ caused either a reduction or an improvement in milk production. Shorter $(\sim 30 \mathrm{~d})$ dry periods had no negative influences that caused detrimental effects on DMI, BW, BCS changes, or apparent health problems during the postpartum period. Cows assigned to the three dry period treatments had almost identical total milk yields at the end of the 21-wk observation period, and 305-d ME milk yields did not differ. Providing ECP at time of dry off did not improve milk production of the 30-d dry group through $21 \mathrm{wk}$ or the 305-d ME milk yields. Based on milk production responses, a $\sim 30$-d dry period was sufficient time for the mammary gland to involute, for epithelial cells to redifferentiate, and for a new lactation to be established. However, follow-up research should be done to study the effect of short dry periods on long term health and longevity in the herd.

\section{ACKNOWLEDGMENTS}

Financial support was provided by the Florida Dairy Farmers Checkoff Project. Excellent assistance at the Dairy Research Unit was provided by the farm crew, especially Mary E. Russell, Carrie Bradley, and other feeders.

\section{REFERENCES}

Akers, R. M., and S. C. Nickerson. 1983. Effects of prepartum blockade of microtubule formation on milk production and biochemical differentiation of the mammary epithelium of heifers. Int. J. Biochem. 15:771-775.

Athie, F., K. C. Bachman, H. H. Head, M. J. Hayen, and C. J. Wilcox. 1996. Estrogen administered at final milk removal accelerates involution of bovine mammary gland. J. Dairy Sci. 79:220-226.

Athie, F., K. C. Bachman, H. H. Head, M. J. Hayen, and C. J. Wilcox. 1997. Milk plasmin during mammary involution that has been accelerated by estrogen. J. Dairy Sci. 80:1561-1568.

Bachman, K. C. 2002. Milk production of dairy cows treated with estrogen at the onset of a short dry period. J. Dairy Sci. 85:797-803.

Bertics, S. J., R. R. Grummer, C. Cadorniga-Valino, and E. E. Stoddard. 1992. Effect of prepartum DMI on liver triglyceride concentration and early lactation. J. Dairy Sci. 75:1914-1922.

Capuco, A. V., R. M. Akers, and J. J. Smith. 1997. Mammary growth in Holstein cows during the dry period: quantification of nucleic acids and histology. J. Dairy Sci. 80:477-487.

Capuco, A. V., and R. M. Akers. 1999. Mammary involution in dairy animals. J. Mammary Gland Biol. Neoplasia. 4:137-144.

Coppock, C. E., R. W. Everett, R. P. Natzke, and H. R. Ainslie. 1974. Effect of dry period length on Holstein milk production and selected disorders at parturition. J. Dairy Sci. 57:712-718.

Dias, F. M., and F. R. Allaire. 1982. Dry period to maximize milk production over two consecutive lactations. J. Dairy Sci. 65:136-145.

Dirksen, G. U., G. H. Liebich, and E. Mayer. 1985. Adaptive changes of the ruminal mucosa and their functional and clinical significance. Bov. Pract. 20:116-120.

Drackley, J. K. 1999. Biology of dairy cows during the transition period: The final frontier. J. Dairy Sci. 82:2259-2273.

Ferguson, J. D., D. T. Galligan, and N. Thomsen. 1994. Principal descriptors of body condition score in Holstein cows. J. Dairy Sci. 77:2695-2703.

Funk, D. A., A. E. Freeman, and P. J. Berger. 1987. Effects of previous days open, previous days dry, and present days open on lactation yield. J. Dairy Sci. 70:2366-2373.

Goff, J. P., and R. L. Horst. 1997. Physiological changes at parturition and their relationship to metabolic disorders. J. Dairy Sci. 80:1260-1268.

Hurley, W. L. 1989. Mammary gland function during involution. J. Dairy Sci. 72:1637-1646. 
Klein, J. W., and T. E. Woodward. 1943. Influence of length of dry period upon the quantity of milk produced in the subsequent lactation. J. Dairy Sci. 26:705-713.

Lascelles, A. K., and C. S. Lee. 1978. Involution of the mammary gland. Page 115 in Lactation. Vol. 4. B. L. Larson, ed. Academic Press, New York and London.

Littell, R. C., G. A. Milliken, W. W. Stroup, and R. D. Wolfinger. 2000. SAS system for mixed models. SAS Institute, Inc., Cary, NC.

Makuza, S. M., and B. T. McDaniel. 1996. Effects of days dry, previous days open, and current days open on milk yields of cows in Zimbabwe and North Carolina. J. Dairy Sci. 79:702-709.

National Research Council. 1989. Nutrient Requirements of Dairy Cattle. 6th rev. ed. Natl. Acad. Press, Washington, DC.

Remond, B., J. Rouel, N. Pinson, and S. Jabet. 1997. An attempt to omit the dry period over three consecutive lactations in dairy cows. Ann. Zootech. 46:399-408.

Schaeffer, L. R., and C. R. Henderson. 1972. Effects of days dry and days open on Holstein milk production. J. Dairy Sci. 55:107-112.
Schairer, M. L. 2001. Estrogen treatments for the initiation of dry off in dairy cows. M.S. Thesis. Univ. Florida, Gainesville.

Smith, A., J. V. Wheelock, and F. H. Dodd. 1966. Effect of milking throughout pregnancy on milk yield in succeeding lactation. J. Dairy Sci. 49:895-896.

Smith, K. L., and D. L. Todhunter. 1982. The physiology of mammary glands during the dry period and the relationship to infections. Page 87 in Proc. Natl. Mastitis Council Louisville, KY. Natl Mastitis Council, Inc. Arlington, VA.

Sorensen, J. T., and C. Enevoldsen. 1991. Effects of dry period length on milk production in subsequent lactation. J. Dairy Sci. 72:1277-1283.

Sorensen, J. T., C. Enevoldsen, and T. Kristensen. 1993. Effects of different dry period lengths on production and economics in a dairy herd estimated by stochastic simulation. Livest. Prod. Sci. 33:77-90.

Swanson, E. W. 1965. Comparing continuous milking with 60-d dry periods in successive lactations. J. Dairy Sci. 48:1205-1209. 